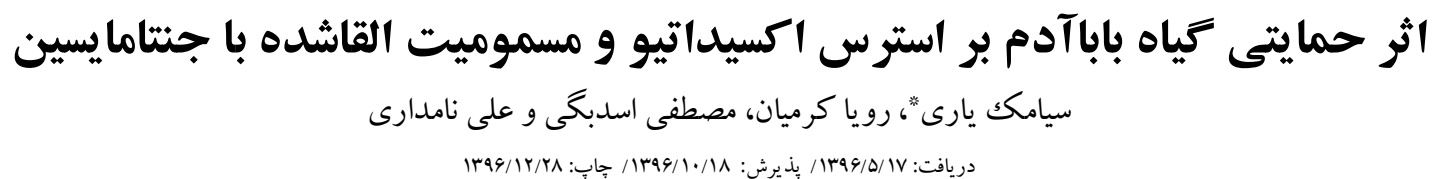

$$
\begin{aligned}
& \text { كروه زيستشناسى، دانشكدة علوم، دانشكاه بوعلى سينا ، همدان، ايران }
\end{aligned}
$$

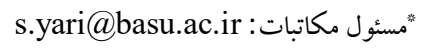

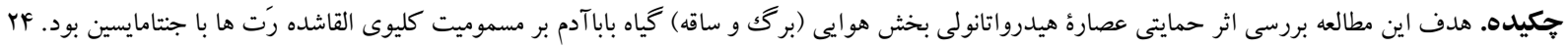

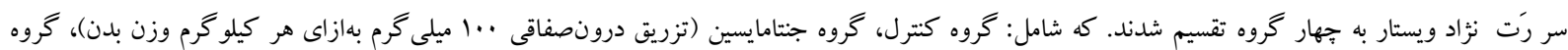

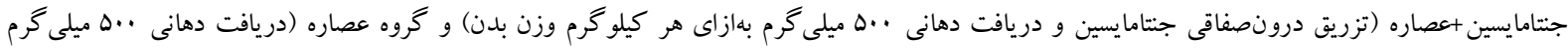

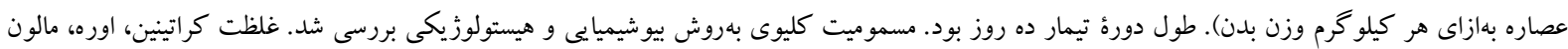

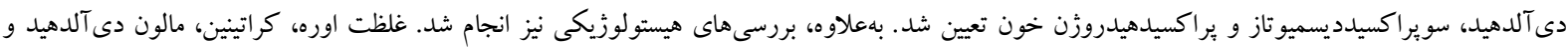

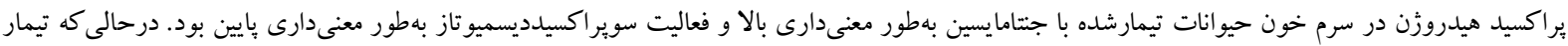

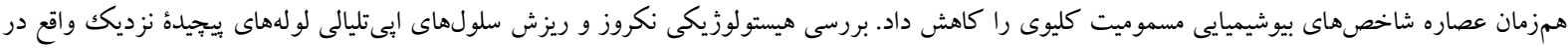

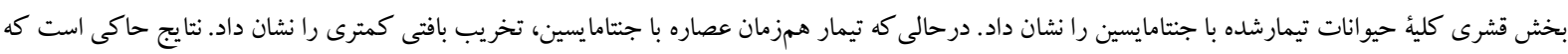

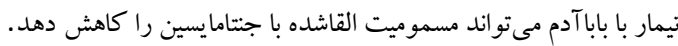

$$
\begin{aligned}
& \text { وازههاى كليدى. بافت كليه، براكسيدهيدروزن، رت، كر آتينين، مالوندى آلدهيد }
\end{aligned}
$$

\title{
Protective effect of Arctium lappa on oxidative stress and nephrotoxicity induced by gentamicin
}

\author{
Siamak Yari*, Roya Karamian, Mostafa Asadbegy \& Ali Namdari \\ Received 08.08.2017/ Accepted 08.01.2018/ Published 19.03.2018
}

Department of Biology, Faculty of Science, Bu-Ali Sina University, Hamedan, Iran

*Correspondent author: s.yari@basu.ac.ir

Abstract. This study aimed to investigate the protective effect of Arctium lappa (AL) on gentamicin (GM)-induced nephrotoxicity in rats. Twenty-four Wistar rats were divided into four groups including: control group; GM group (intrapritoneal injection, IP, of $100 \mathrm{mg} / \mathrm{kg} \mathrm{GM} \mathrm{B.W.);} \mathrm{GM+AL} \mathrm{group} \mathrm{(received} \mathrm{IP} \mathrm{injection} \mathrm{of} 100 \mathrm{mg} / \mathrm{kg} \mathrm{GM}$ and 500 $\mathrm{mg} / \mathrm{kg} \mathrm{AL}$ orally) and $\mathrm{AL}$ group (received $500 \mathrm{mg} / \mathrm{kg} \mathrm{AL}$ orally). The experimental period lasted for 10 days. Nephrotoxicity was biochemically and histologically evaluated. The concentrations of creatinine, urea, malondialdehyde (MDA), superoxide dismutase (SOD) and peroxide hydrogen $\left(\mathrm{H}_{2} \mathrm{O}_{2}\right)$ in the serum samples were determined. Moreover, histological examinations were performed. The animals treated with gentamicin showed significantly higher serum urea, creatinine, MDA and $\mathrm{H}_{2} \mathrm{O}_{2}$ levels and lower SOD activity. However, co-administration of AL produced amelioration in biochemical indices of nephrotoxicity in serum. Histomorphological examination showed necrosis and desquamation of tubular epithelial cells in the renal cortex in animals treated with gentamicin whereas simultaneous administration of AL and GM reduced histological damages. The data obtained suggest that treatment with AL extract can help to reduce gentamicin-induced nephrotoxicity.

Keywords. creatinine, hydrogen peroxide, kidney tissue, malondialdehyde, rat 
آر كتينين، كافئيك اسيد، كلوروزنيك اسيد، اينولين، لإيائول، دى -

مقدمه

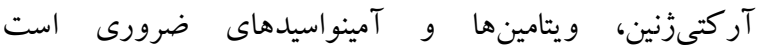

Miyamoto et al., 1993; Park et al., 2007; Hirose et )

(al., 2000 همجنين، در جو امع مختلف از بخشهاى مختلف اين

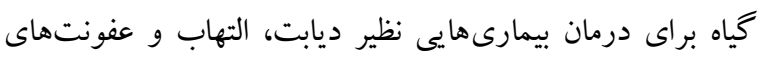

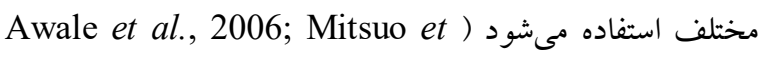

.(al., 2005

هدف اين مطالعه، بررسى نقش حمايتى مصرف عصارة

هيدرواتانولى گياه باباآدم دربرابر آسيبهاى ناشى آنس از مصرف

آنتىبيو تيك جنتامايسين بر كليهها است.

\section{مواد و روشها}

مواد شيميايى: همٔ مواد شيميايى و حلالهاى استفاده شده در

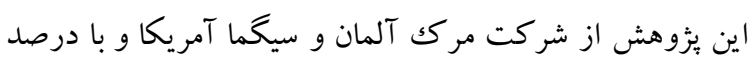

خلوص بالا تهيه شده است.

مواد كياهى و استخراج عصاره كياهى: گياه بابآدم در ماه ارديبهشت از زيستكاههاى طبيعى خود (آذربايجانشرقى) در سال

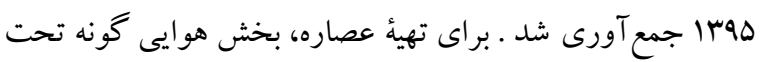

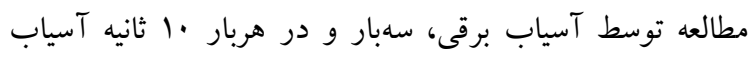

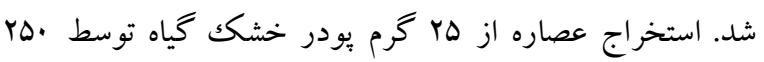
ميلى ليتر اتانول خالص و بهوسيلة دستخاه استخراج كنندة سو كسله

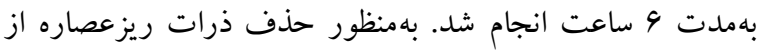
كاغذ صافى واتمن استفاده شد. سبس، عصارهها تا زمان استفاده

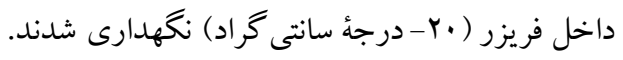

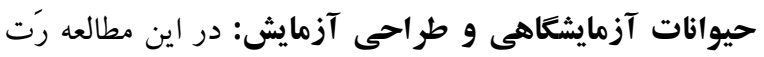

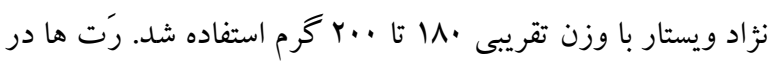

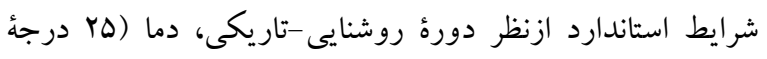

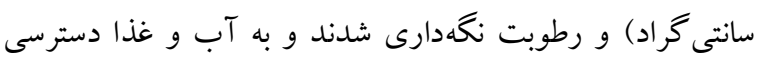

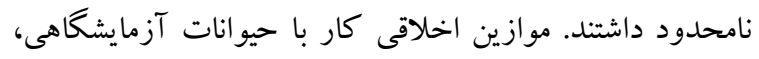

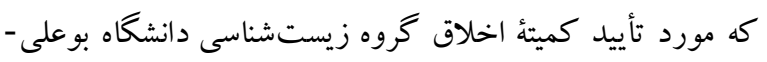

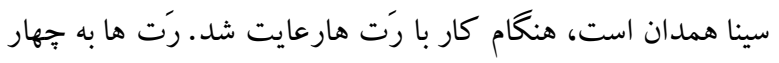

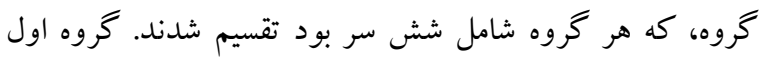

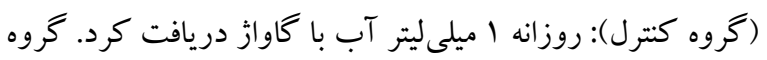

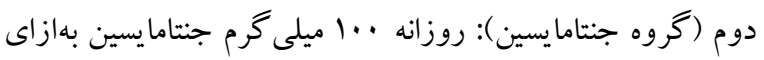

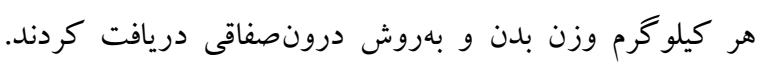

جنتاما يسين يكك آنتى بيوتيك آمينو گليكوزيدى است كه استفاده

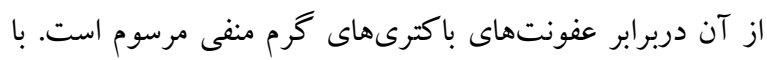

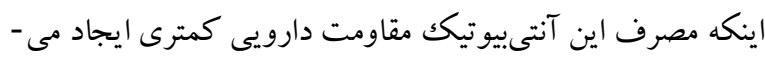

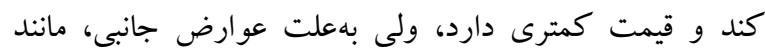

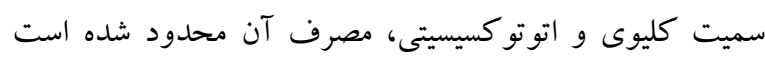
(Humes, 1988) مصرف، در بدن متابوليزه نمىشوند و بهطور عمده ازطريق ادار

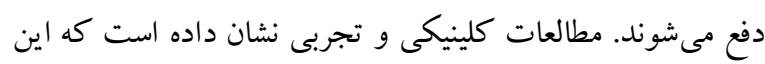

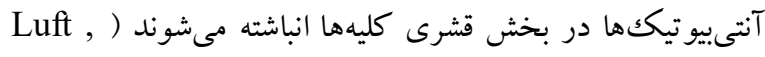
1974; Edwards et al., 1976; Schentag et al., 1977; (Luft et al., 1978

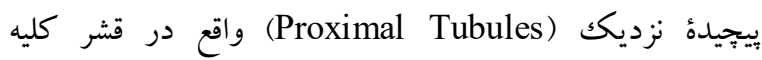
بازجذب مىشود و بهنظر مىرسد انباشت اين ماده در لولههاى

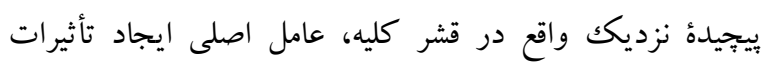

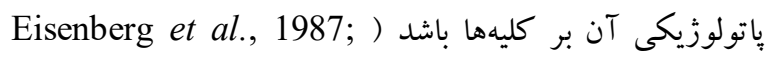
.Houghton et al., 1976 سازو كار اصلى كه بهواسطة آن جنتامايسين باعث نفروتو -

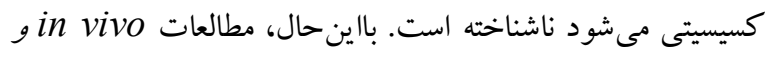

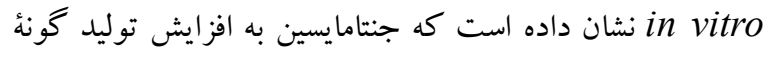
اكسيزن فعال (Reactive Oxigen Species=ROS) منجر مى -

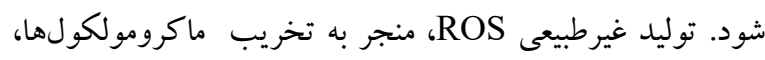

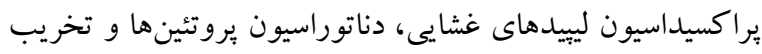

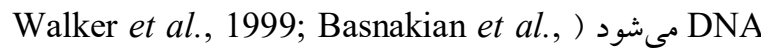
2002). روشهاى متفاوتى براى جلو گيرى از نفروتو -كسيسيتى

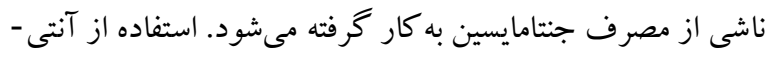

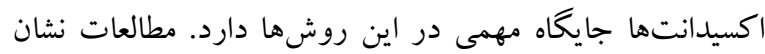

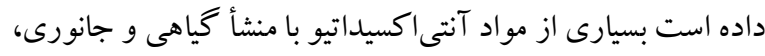
مىتواند با مسموميت ناشى از مصرف جنتامايسين مقابله كنند Abdel-Naim, 1999; McCall \& Frei, 1999; ) .(Maldonado et al, 2003; Stahl \& Sies, 2003 گياه بابآدم گياهى خندساله از خانواده كمبوزيته و داراى يراكنش جهانى است. و در بسيارى از نقاط جهان بهمثابٔ گياه دارويى استفاده مىشود (Morita et al., 1993). مطالعات نشان داده است كه اين گياه داراى مواد مؤثر فعالى شامل تانن، 
سبس ه/ • ميلىليتر از محلول سانتر يفوزشده به ه/· ميلىليتر بافر

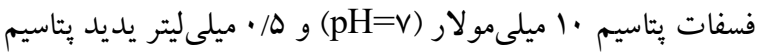

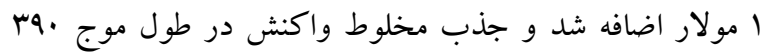
نانومتر خوانده شد. مقادير يراكسيد هيدروزن در هر نمونه با

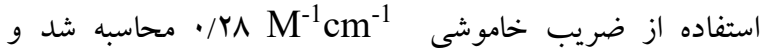
برحسب ميكرومول بر خرم وزن بافت گزارش شد ( Velikova et (al., 2000 غلظت سنجش ميزان آنزيم سوير اكسيد ديسميوتاز:

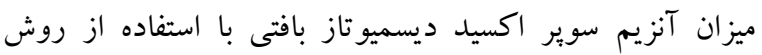
Fridovich و سنجيده شد (1971). بررسىهاى هيستولوزيكى: كلئ جداشده با استفاده از سرم فيزيولوزيكى شستوشو شد و در فرمالين ·ا درصد تثبيت شد. سبس، با درجات صعودى اتانول، آبخيرى و توسط يُرارافين قالبگيرى شد. نمونهاى قالب گيرىشده با پارافين توسط دستخاه

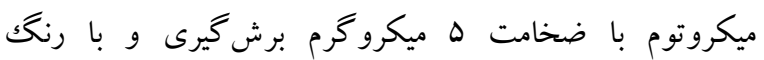

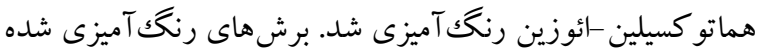

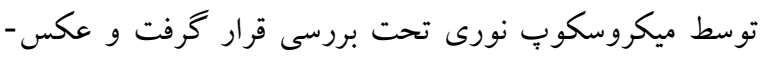

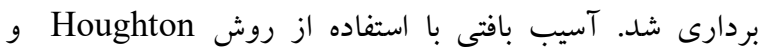
همكاران (1978)و مطابق جدول ارتبهبندى شد.

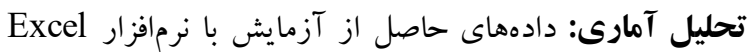

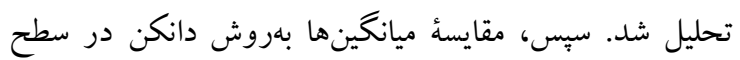

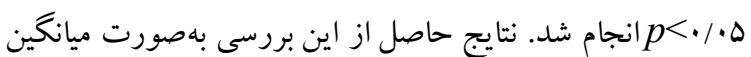
t|تانحر اف معيار بيان شد.

نتايج تأثير جنتامايسين و بابآدم بر هيستوياتولوزى بافت كليه

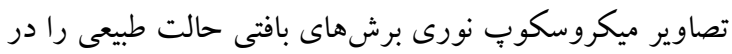
برشهاى متعلق به گروه كنترل و گروه تيمارشده با عصاره گياه

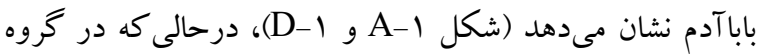

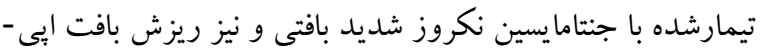

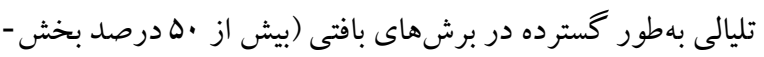

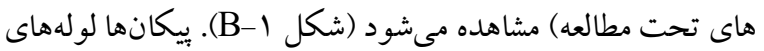
تخريبشده را نشان مىدهد. در گروه كنترل، كه تيمار همزمان

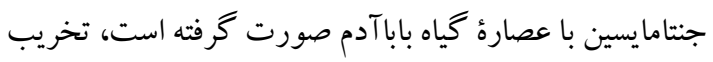

كروه سوم (كروه جنتامايسين و عصارهٔ باباآدم) بهصورت همزمان

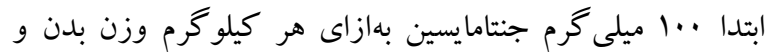

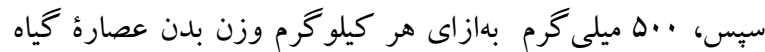
بابآدم دريافت كردند (مشاهدات قبلى كه روى اين گياه و در دوزهاى مختلف و در مدلهاى مختلف صورت گرفته است نشان

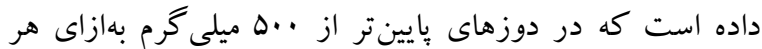

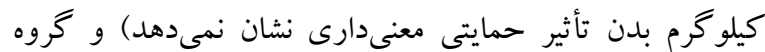

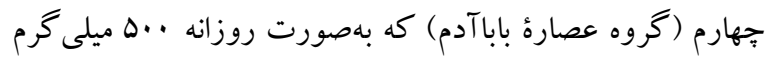

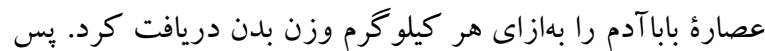
از طىشدن دوره مطالعه ( • اروز )، حيو انات با تنفس دوز بالاى اتر

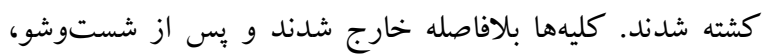

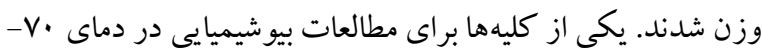
درجة سانتى گراد نگكدارى شد و كلئ ديخر جهت مطالعات هيستويا تولوزيكى به فرمالين ·ا درصد منتقل شد. تحليل هاى بيوشيميايى سنجش ميزان اوره و كراتينين سرم خون: ميزان اوره و كراتينين سرم خون با استفاده از كيت تشخصى مخصوص (شر كت يارس آزمون ايران) سنجيده شد.

سنجش مالوندى آلدئيد (MDA): نمونهاى بافت كليه در

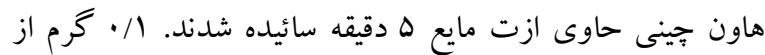
بخش قشرى بافت كلئ سائيدهده درون ميكروتيوب r ميلىليترى ريخته شد و ا ميلىليتر ترى كلرواستيك اسيد (TCA) / / درصد

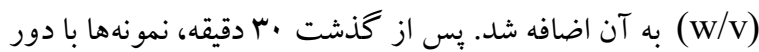
ا..... لوله آزمايش منتقل شد و F ميلىليتر TCA ·r درصد محتو اي ه/ • درصد تيوباربيتوريك اسيد به آن اضافه شد. نمونهها در بن مارى و در دماى هو درجة سانتى گراد بهمدت ها دقيقه قرار گرفتند.

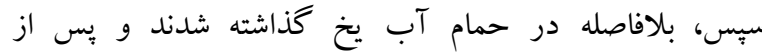

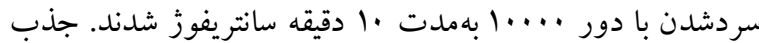
نمونهها در Yrهه نانومتر خوانده شد. مقادير MDA برحسب ميلى كرم بر گرم وزن بافت گز ارش شد (Baryla et al., 2000). سنجش :براكسيد هيدروزن: براى سنجش مقادير ڤبراكسيد

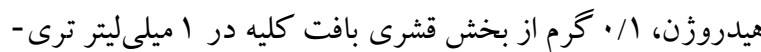
كلرو استيك اسيد // مولار (TCA) ساييده شد و بعد عصارههاى حاصل با دور ....1 بهمدت •ا دقيقه سانتريفوز شدند. 

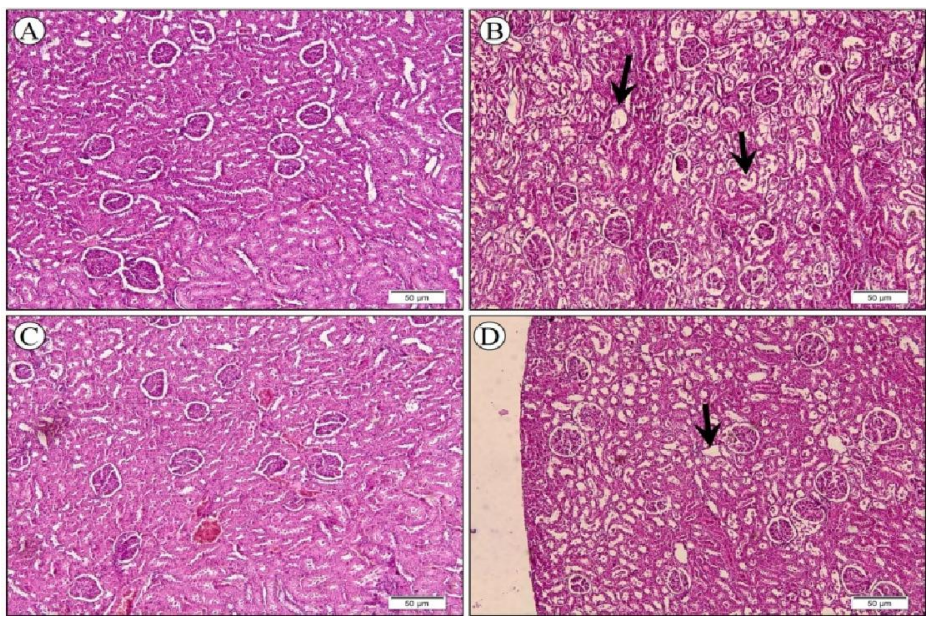

شكل ا - فتوميكروگر اف برشهاى كليه A: برشهاى بافتى گروه كنترل ساختار طبيعى را نشان مىدهند. B: برشهاى بافتى گروه جنتامايسين تخريب بافتى و ريزش

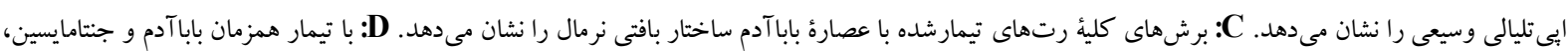
برش هاى كليه تخريب ملايمى را نشان مىدهد.

Fig. 1. Photomicrograph of kidney sections A: control sections showing normal architecture; B: gentamicin treated rat showing intense epithelial desquamation. C: AL treated rats show normal structure D: AL extract plus gentamicin treated rat show mild tubular injuries.

$$
\text { جدول 1-رتبهندى تخريب بافتى كليه در گروههاى مختلف. }
$$

Table 1. Histological damage scoring in different groups.

\begin{tabular}{|c|c|}
\hline رتبه & ميزان تخريب بافتى \\
\hline نرمال & تخريب بين · تا هץ در صد \\
\hline كم & تخريب بين هץ تا •هدر صد \\
\hline متوسط & تخريب بين .ه تا هV در صد \\
\hline شديد & تخر يب بالاتر از Vه درصد \\
\hline
\end{tabular}

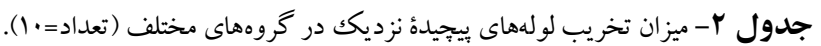

Table 2. Histological damages in different treated groups $(n=10)$.

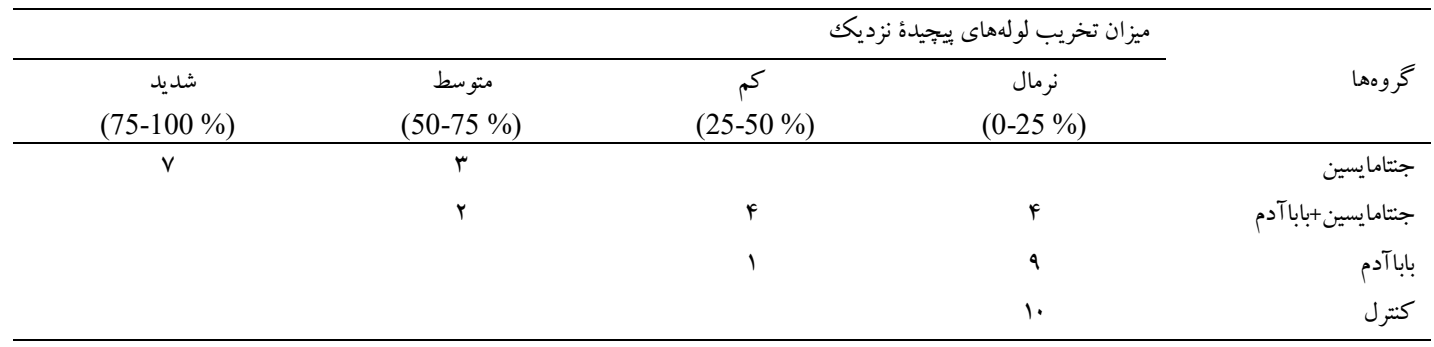

مالون دى آلدهيد (MDA) بهعنوان محصول يراكسيداسيون

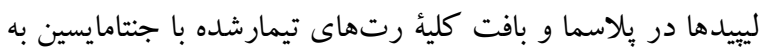
شكل معنى دارى افزايش يافت. تيمار همزمان بابآدم و جنتامايسين

به كاهش معنى دارى در ميزان MDA موجود در يهاسما و بافت
بسيار كم در لولههاى نزديكك مشاهده مىشود (كمتر از له درصد). همجنين، در تمامى گروهها، گَلومرولها حالت طبيعى

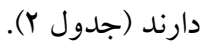

تأثير جنتامايسين و بابا آدم بر سطوح MOD و 
جدول بr- يارامترهاى بيوشيميايى مختلف در گروههاى مختلف.

Table 3. Different biochemical parameters in different groups.

\begin{tabular}{|c|c|c|c|}
\hline \multicolumn{3}{|c|}{ بارامترهاى بيوشيميايى } & \multirow[b]{2}{*}{ نمونهما } \\
\hline 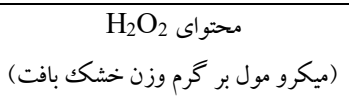 & 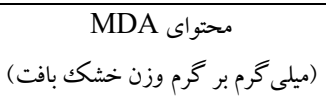 & 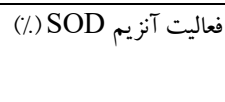 & \\
\hline$\cdot / 1 \cdot 1 \pm \cdot / \cdot \cdot v^{\mathrm{a}}$ & $\cdot / \cdot \wedge q \pm \cdot / \cdot r^{a a}$ & $\Delta I / A V \pm I / r^{a}$ & جتامايسين \\
\hline$\cdot / \cdot \Delta \Delta \pm \cdot / \cdot \cdot \mu^{b}$ & $\cdot / \cdot v) \pm \cdot / \cdot r^{b}$ & $99 / \wedge \& \pm \cdot / q^{b}$ & جنتاما يسين+بابا آدم \\
\hline $.1 .91 \pm .1 . .9^{b}$ & $.1 .99 \pm \cdot / . . q^{b}$ & $V^{4} / 99 \pm \cdot / V^{b}$ & بابآدم \\
\hline$\cdot / \cdot \Delta \wedge \pm \cdot / \cdot \cdot v^{b}$ & $\cdot / \cdot v r \pm \cdot / \cdot 1 \cdot b$ & $W / N T \pm 1 / q^{b}$ & كنترل \\
\hline
\end{tabular}

The values, are mean of three repetition \pm SD. The same letters indicate no significant difference at $p<0.05$.

جدول ع-ميزان اوره و كراتين سرم خون در گروههاى مختلف.

Table 4. The level of urea and serum creatinine in different groups.

\begin{tabular}{|c|c|c|}
\hline \multicolumn{2}{|c|}{ يار امترهاى بيوشيميايى } & \multirow[b]{2}{*}{ نمونها } \\
\hline اوره (ميلى گرم بر دسى ليتر) & كراتينين (ميلى گرم بر دسى ليتر) & \\
\hline $9 V / \Delta 1 \pm r / r^{\mathrm{a}}$ & $r / r \cdot \pm \cdot / r^{a}$ & جنتامايسين \\
\hline$\Delta \cdot \pi \pi_{1 / a^{b}}$ & $1 / r \cdot \pm \cdot / I V^{b}$ & جنتامايسين+باباآدم \\
\hline$r q / 11 \pm \cdot / 9^{c}$ & $\cdot 11 \cdot \pm \cdot / \cdot 9^{\mathrm{c}}$ & بابآدم \\
\hline Yr/FG $\pm \cdot 19^{\mathrm{C}}$ & $\cdot N 1 \pm \cdot / \cdot r^{c}$ & كنترل \\
\hline
\end{tabular}

مقادير، ميانگين ץ تكرار SD I است. حروف يكسان بيانگر عدم اختلاف معنىدار در سطح

The values, are mean of three repetition $\pm \mathrm{SD}$. The same letters indicate no significant difference at $p<0.05$.

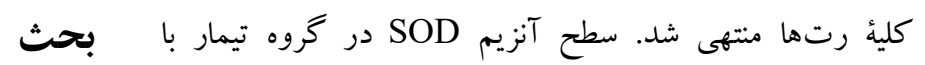
استرس اكسيداتيو در سميت كليوى القاشده توسط جنتامايسين

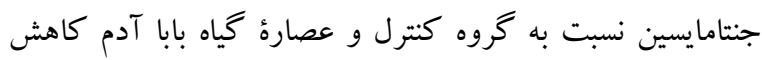
نقش اصلى را برعهده دارد. آمينو كليكوزيدهايى نظير جنتامايسين معنى دارى داشت درحالى كه تيمار همزمان جنتامايسين با عصارة

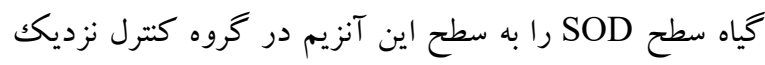
نمى تو انند درون بدن متابوليزه شوند و جنتامايسين مصرفى ازطريق

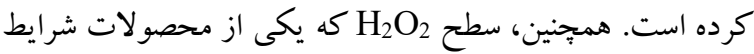

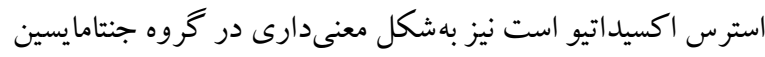
انباشته مىشود (Luft 1974; Mingeot-Leclercq, 1999). درواقع، مطالعات نشان داده است كه انباشت جنتامايسين مسئول

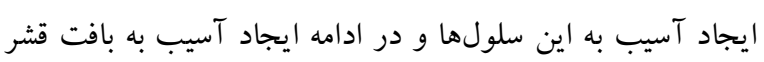

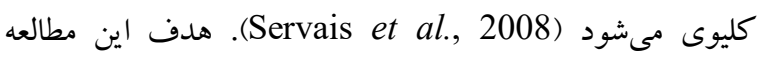
بررسى تأثير آنتىاكسيداتيو باباآدم بر تغييرات بيوشيميايى و بافت شناسى ايجادشده توسط جنتامايسين بود. مطالعات نشان داده است كه در وضعيت استرس اكسيداتيو براكسيداسيون ليبيدها افزايش بيدا مى كند و درنتيجه محصول بيراكسيداسيون لييدها باعنوان

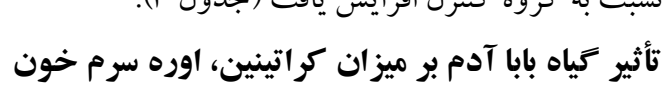

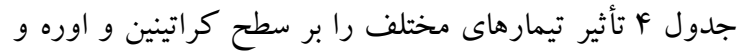

$$
\begin{aligned}
& \text { بلاسماى خون نشان مىدهد. همانطور كه در اين جدول مشاهده }
\end{aligned}
$$

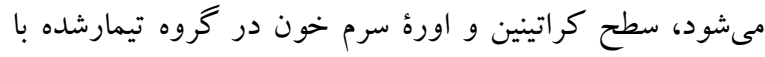

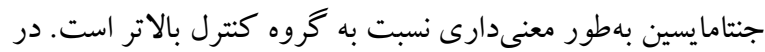

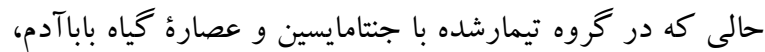

$$
\begin{aligned}
& \text { سطح كراتينين و اوره نسبت به گروه تيمار با جنتاما يسين تنها بهطور } \\
& \text { معنىدارى كاهش يافت. }
\end{aligned}
$$


ميزان آنزيم SOD تا حد گروه كنترل شد. همجينين، تيمار همزمان جنتامايسين و گياه باباآدم ميزان داد كه نشاندهندة افزايش ميزان آنزيم كاتالاز است ( Baliga et .al., 1999; Moreira et al., 2014 يافتهاى هيستولوزيكى نيز دادههاى بيوشيميايى بررسى تغييرات

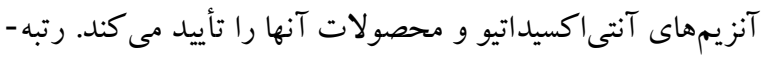

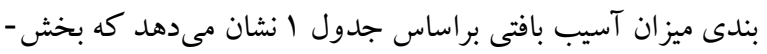

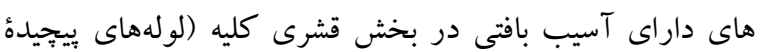
نزديكى) داراى گسترش وسيعى است (بيش از •هد درصد) و شامل

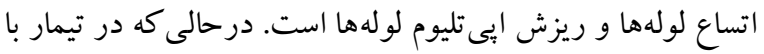

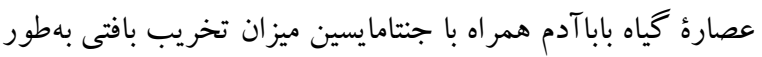
مشهودى كاهش مى يابد (كمتر از •ه درصد). اين يافته بافت-

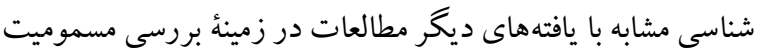
Karatas et al., 2004; Juan ) كليوى ناشى از جنتامايسين است بنائهاي

.et al., 2006; Basnakian et al., 2002

نتيجه كيرى

بهطور خلاصه مىتوان كفت كه يكى از مهمترين تأثير باتولوزيكى جنتامايسين بر كليه، تأثير تخريبى اين آنتىبيوتيك بر

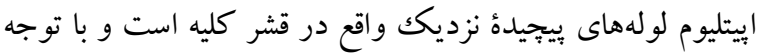

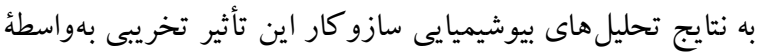
تأثير استرس اكسيداتيو است كه كاهش ميزان آنزيمهاى آنتى اكسيداتيو و افزايش محصولات حاصل از يراكسيداسيون غشاها تأييد كنندة اين تأثير ات است. از سويى، عصاره بخش هوايى گياه

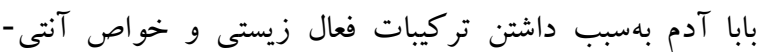
اكسيدانى قوى، باعث افزايش آنزيمهاى آنتىاكسيداتيو و كاهش بـ يراكسيداسيون غشا مىشوند. در نتيجه استفاده از عصارة اين گياه مىتواند به عنوان يك مكمل مناسب جهت كاهش تأثيرات مخرب هيستوياتولوزيكى و بيوشيميايى مىشود.

سياسگز ارى از دكتر ابراهيم طالع فاضل كه امكانات لازم جهت عكسبردارى

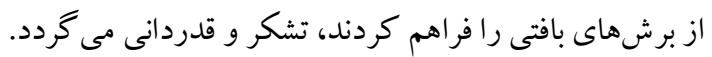

\section{REFERENCES}

MDA در بافتها و سرم جانور درمعرض استرس اكسيداتيو

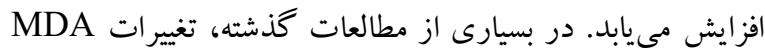
در نتيجة مسموميت كليوى القاشده با جنتامايسين مشاهده شده Parlakpinar et al., 2005; Maldonado et al., ) است 2003; Kuhad et al., 2006 جنتامايسين به افزايش مالون دى آلدهيد بافتى منجر شد، درحالى -

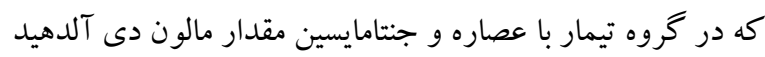
بهشكل معنىدارى كاهش يافت (جدول r). مطالعات دربارئ

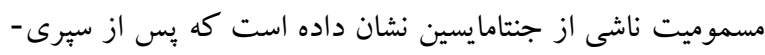
شدن مدتزمان لازم همراه با مقدار مصرفى مناسب (..1 ميلى-

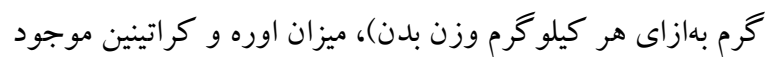

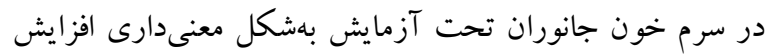

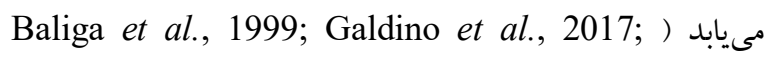
(Humes, 1988 جنتامايسين بهشكل معنىدارى باعث افزايش اوره و كراتينين سرم

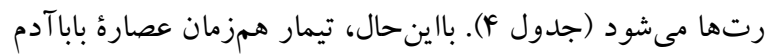

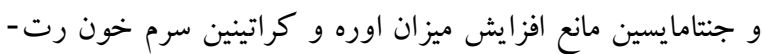
هاى متعلق به گروه جنتامايسين و عصاره شد و ميز ان اين دو بار امتر ميز

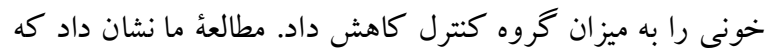
ميزان آنزيم آنتى اكسيدانت SOD،

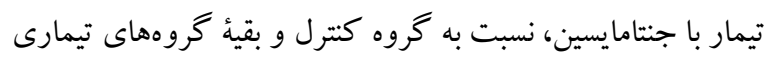

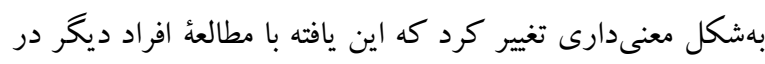

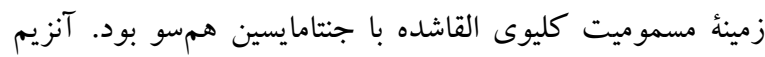
يكى از آنزيمهاى مهم مقابله كننده با استرس اكسيداتيو است و به تبديل سويراكسيد به براكسيد-هيدروزن منجر مى شود.

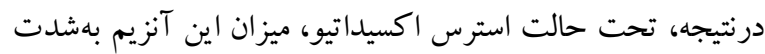
كاهش مىيابد و كاهش سطح اين آنزيم نشاندهنده افزايش

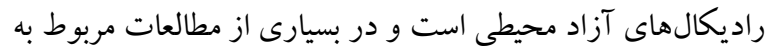
مسموميت ناشى از جنتامايسين نيز كاهش شديد اين آنزيم مشهود

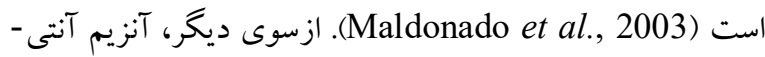
اكسيدانت ديخر كه كاتالاز نام دارد باعث خنثىسازى ماده اكسيداتيو پراكسيد هيدروزن در بدن مىشود؛ پِّ، افزايش سطح اين ماده (يراكسيد هيدروزن)، بططور غيرمستقيم نشاندهنده

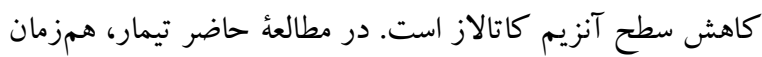
جنتامايسين و عصاره بخش هاى هو ايى گياه بابآدم، باعث افز ايش داصن 
Abdel-Naim, A.B., Abdel-Wahab, M.H., and Attia, F.F. 1999. Protective effects of vitamin E and probucol against gentamicin-induced nephrotoxicity in rats. Pharmacol. Res. 40: 183-187.

Awale, S., Lu, J., Kalauni, S.K., Kurashima, Y., Tezuka, Y., Kadota, S., and Esumi, H. 2006. Identification of arctigenin as an antitumor agent having the ability to eliminate the tolerance of cancer cells to nutrient starvation. - Cancer Res. 66:1751-1757.

Baliga, R., Ueda, N., Walker, P.D., and Shah, S.V. 1999. Oxidant mechanisms in toxic acute renal failure. Drug Metab. Rev. 31: 971-997.

Baryla, A., Laborde, C., Montillet, J.L., Triantaphylides, C. and Chagvardieff, P. 2000. Evaluation of lipid peroxidation as a toxicity bioassay for plants exposed to copper. - Environ. Pollut. 109: 131-135.

Basnakian, A.G., Kaushal, G.P. and Shah, S.V. 2002. Apoptotic pathways of oxidative damage to renal tubular epithelial cells. - Antioxid. Redox. Signal 4: 915-924.

Edwards, C.Q., Smith, C. R., Baughman, K. L., Rogers, J.F., and Lietman, P.S. 1976. Concentrations of gentamicin and amikacin in human kidneys. Antimicrob. Agents Chemother. 9: 925-927.

Eisenberg, J.M., Koffer, H., Glick, H.A., Connell, M.L., Loss, L.E., Talbot, G.H., and Strom, B.L. 1987. What is the cost of nephrotoxicity associated with aminoglycosides? - Ann. Intern. Med. 107: 900-909.

Galdino, P.M., Alexandre, L.N., Pacheco, L.F., Junior, R.D.S.L., de Paula, J.R., Pedrino, G.R., and Ferreira, P.M. 2017. Nephroprotective effect of Rudgea viburnoides (Cham.) Benth. leaves on gentamicininduced nephrotoxicity in rats. - J. Ethnopharmacol. 201: 100-107.

Hirose, M., Yamaguchi, T., Lin, C., Kimoto, N., Futakuchi, M., Kono, T., Nishibe, S. and Shirai, T. 2000. Effects of arctiin on PhIP-induced mammary, colon and pancreatic carcinogenesis in female Sprague-Dawley rats and MeIQx-induced hepatocarcinogenesis in male F344 rats. - Cancer Lett. 155: 79-88.

Houghton, D.C., Plamp 3rd, C.E., DeFehr, J.M., Bennett, W.M., Porter, G., and Gilbert, D. 1978. Gentamicin and tobramycin nephrotoxicity. A morphologic and functional comparison in the rat. Am. J. Pathol. 93: 137-152.

Humes, H.D. 1988. Aminoglycoside nephrotoxicity. Kidney International. 33: 900-911.

Juan, S.H., Chen, C.H., Hsu, Y.H., Hou, C.C., Chen, T.H., Lin, H., Chu, Y.L. and Sue, Y.M. 2006. Tetramethylpyrazine protects rat renal tubular cell apoptosis induced by gentamicin. - Nephrol Dial Transplant. 22: 732-739.

Karataş, Y., Seçilmiş, M.A., Karayaylalı, İ., Doran, F., Büyükafşar, K., Şingirik, E., Saglıker, Y. and Dikmen, A., 2004. Effect of tempol (4-hydroxy tempo) on gentamicin-induced nephrotoxicity in rats. - Fundam Clin Pharmacol. 18: 79-83.

Kuhad, A., Tirkey, N., Pilkhwal, S., and Chopra, K. 2006. Effect of Spirulina, a blue green algae, on gentamicin-induced oxidative stress and renal dysfunction in rats. - Fundamental \& Clinical Pharmacology. 20: 121-128.

Luft, F.C. 1974. Renal parenchymal accumulation of aminoglycoside antibiotics in rats. - J. Infect. Dis. 130: 656-659.

Luft, F.C., Bloch, R., Sloan, R.S., Yum, M.N., Costello, R. and Maxwell, D.R. 1978. Comparative nephrotoxicity of aminoglycoside antibiotics in rats. J. Infect. Dis. 138: 541-545.

Maldonado, P.D., Barrera, D., Medina-Campos, O.N., Hernández-Pando, R., Ibarra-Rubio, M.E., and Pedraza-Chaverrí, J. 2003. Aged garlic extract attenuates gentamicin induced renal damage and oxidative stress in rats. - Life Sci. 73: 2543-2556.

Maldonado, P.D., Barrera, D., Rivero, I., Mata, R., Medina-Campos, O.N., Hernández-Pando, R., and Pedraza-Chaverrí, J. 2003. Antioxidant Sallylcysteine prevents gentamicin-induced oxidative stress and renal damage. - Free Radic. Biol. Med. 35: 317-324.

McCall, M.R., and Frei, B. 1999. Can antioxidant vitamins materially reduce oxidative damage in humans? - Free Radic. Biol. Med. 26: 1034-1053.

Mingeot-Leclercq, M.P. and Tulkens, P.M. 1999. Aminoglycosides: nephrotoxicity. - Antimicrob. Agents Chemother. 43: 1003-1012.

Mitsuo, M., Nobuo, Y., and Katsuya, T. 2005. Inhibitory compounds of alpha glucosidase activity from Arctium lappa L. - J. Oleo. Sci. 54: 589-594

Miyamoto, K., Nomura, M., Sasakura, M., Matsui, E., Koshiura, R., Murayama, T., Furukawa, T., Hatano, T., Yoshida, T., and Okuda, T. 1993 Antitumoractivity of oenothein-B, a unique macrocyclic ellagitannin. - Japanian J. Cancer Res. 84: 99-103.

Moreira, M.A., Nascimento, M.A., Bozzo, T.A., Cintra, A., da Silva, S.M., Dalboni, M.A., and Higa, E.M. 2014. Ascorbic acid reduces gentamicin-induced nephrotoxicity in rats through the control of reactive oxygen species. - Clin. Nutr. 33: 296-301.

Morita, T., Ebihara, K., and Kiriyama, S. 1993. Dietary fiber and fat derivatives prevent mineral-oil toxicity in rats by the same mechanism. - J. Nutr. 123: 15751585.

Park, S.Y., Hong, S.S., Han, X.H., Hwang, J.S., Lee, D., Ro, J.S., and Hwang, B.Y. 2007. Lignans from Arctium lappa and their inhibition of LPS-induced nitric oxide production. - Chem. Pharm. Bull. 55: 150-152.

Parlakpinar, H., Tasdemir, S., Polat, A., Bay-Karabulut, A., Vardi, N., Ucar, M., and Acet, A. 2005. Protective role of caffeic acid phenethyl ester (cape) on gentamicin-induced acute renal toxicity in rats. Toxicology 207: 169-177.

Schentag, J.J., Jusko, W.J., Vance, J.W., Cumbo, T.J., Abrutyn, E., DeLattre, M., and Gerbracht, L.M. 1977. Gentamicin disposition and tissue accumulation on multiple dosing. - J. Pharmacokinet. Biopharm. 5: 559-577.

Servais, H., Ortiz, A., Devuyst, O., Denamur, S., Tulkens, P.M. and Mingeot-Leclercq, M.P., 2008. Renal cell apoptosis induced by nephrotoxic drugs: 
cellular and molecular mechanisms and potential approaches to modulation. - Apoptosis 13: 11-32.

Stahl, W., and Sies, H. 2003. Antioxidant activity of carotenoids. - Mol. Aspects Med. 24: 345-351.

Velikova, V., Yordanov, I. and Edreva, A. 2000. Oxidative stress and some antioxidant systems in acid rain-treated bean plants: protective role of exogenous polyamines. - Plant Sci. 151: 59-66.

Walker, P.D., Barri, Y., and Shah, S.V. 1999. Oxidant mechanisms in gentamicin nephrotoxicity. - Renal Failure 21: 433-442.

$$
* * * * *
$$

How to cite this article:

Yari, S., Karamian, R., Asadbegy, M. and Namdari, A. 2018. Protective effect of Arctium lappa on oxidative stress and nephrotoxicity induced by gentamicin. - Nova Biologica Rep. 4: 353-360.

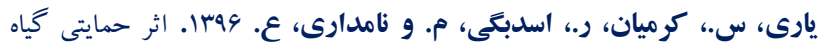

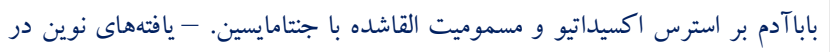

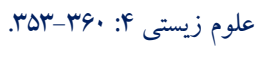

